\title{
Implementation of Linear Congruent Method For Guess the Drawing
} Game

\author{
${ }_{1}$ R. Mahdalena Simanjorang, ${ }^{2}$ Agustina Simangunsong \\ ${ }^{1}$ Informatics Engineering Study Program, STMIK Pelita Nusantara \\ ${ }^{2}$ Informatics Management Study Program, STMIK Pelita Nusantara \\ Email : lenasinaga13@gmail.com ${ }^{1}$, agustinasimangunsong93@gmail.com ${ }^{2}$
}

\begin{tabular}{ll}
\hline Keywords & $\begin{array}{l}\text { Abstract. In face guessing game is a game with pictures that will be scrambled and } \\
\text { questions in this guess the face game application. Linear Congruent methods are used to } \\
\text { generate random values used to randomize images and questions displayed on the guess }\end{array}$ \\
the face game. Random value generation will be used in this game using lcm formula Xn = \\
Guess the Face \\
(andom Values \\
effect on the random value displayed. The ever-changing administration of a, Xn and b can \\
avoid fixed or repetitive patterns of consecutive random value generation effects. In \\
addition, the provision of variable changes can also prevent the repetition of questions that \\
will be randomized in a row. While to avoid the exit of unwanted random values and used \\
variable m as a limiter maximum value. The implementation of the above method can be \\
concluded that the game guess the face of badminton athletes displays varied images and \\
questions that users can play with their respective difficulty levels.
\end{tabular}

\section{INTRODUCTION}

Gaming is an exciting activity or entertainment in humans. If the game used to be just a child monopoly, it's the case now. Today's game can already be said to be a universal toy. Starting from toddlers, young people to adults are no longer familiar with the name of the game[1]. If people might only know GameWatch or GameBoy in the past, nowadays people can choose various game media[2]. To play games, currently just choose, want to use a desktop computer (PC) or through a laptop, mobile phone or can also through the manufacturer's game equipment such as PlayStation or Xbox. In most problems, to randomize a face it only takes speed to generate large numbers randomly and fast time. Therefore many face guessing games fail through statistical tapdoman testing[3].

Linear Congruent Method (LCM) is a random number generation method widely used in computer programs[4]. Algorithms or methods used to generate random numbers that appear to be no repetitions[5]. A random number generated by a computer is a pseudo-random number, because the generation uses arithmetic operations and pseudo rand generatomors (PRG) in general. The determination of LCM constants ( $\mathrm{a}, \mathrm{c}$ and $\mathrm{m}$ ) determines whether or not to determine the random number to be projected so that no repetition occurs[6][7].

\section{METHOD}

In designing the application the author creates a design procedure that aims to draw up the necessary ordinances and steps to achieve research objectives. The design procedure uses the following working steps:

1) Data Collection

Ensure the data to be used in the Game development process.

2) Identify The Problem

Study existing systems and analyze problems to determine the needs of the necessary set and techniques and find limitations. To choose the most effective way of completing and will provide the required solutions and benefits to be obtained

3) Literature Studies

At this stage is done to search for data by reading and studying various books, the internet and knowledge related to the problem that will be researched, namely games using $1 \mathrm{~cm}$ method

4) Method Implementation

This stage is the use of LCM method

5) Results and Discussion Outline the results in the study.

Jurnal Info Sains : Informatikan dan Sains is licensed under a Creative Commons Attribution-Non Commercial 4.0 International License (CC BY-NC 4.0) 


\subsection{Linear Congruent Methods (LCM)}

Linear Congruent Method (LCM) generates random numbers that are widely used in computer programs[8]. Algorithms or methods used to generate random numbers that appear to be no repetitions. A random number generated by a computer is a pseudo-random number, because the generation uses arithmetic operations and pseudo random generators (PRG) in general. The determination of the CONSTANT LCM $X_{n}=\left(\left(a\left(X_{n}-1\right)+b\right)\right)$ determines whether or not to specify a random number to be produced so that no repetition occurs. LCM utilizes linear models to generate random numbers in this thesis can be defined by[9]:

$\mathrm{Xn}=(((\mathrm{a}(\mathrm{Xn}-1)+\mathrm{b}))$ mod $\mathrm{m}$ Where $: \mathrm{Xn}$ is the $\mathrm{nth}$ random number of the series $\mathrm{Xn}-1$ is the previous random number $a$ is the switch factor $b$ is the increase ( increment) $m$ is modulus (maximum limit of random numbers) $\mathrm{a}, \mathrm{b}$ and $\mathrm{m}$ is the constant $\mathrm{LCM}[10]$.

\section{RESULTS AND DISCUSSION}

Face guessing game is a face guessing game. Like other face guessing games, every face that the player can successfully guess correctly will be rated in this game. The value obtained by the player is denoted by the nominal rupiah The value of each question can be seen in the following table.

\begin{tabular}{ccc}
\multicolumn{3}{c}{ Table 1. Value table of Each Question } \\
\hline No & Question & Score \\
\hline 1 & Question 1 & 10 \\
2 & Question 2 & 20 \\
3 & Question 3 & 30 \\
4 & Question 4 & 40 \\
$\mathbf{5}$ & Question 5 & $\mathbf{5 0}$ \\
6 & Question 6 & 60 \\
7 & Question 7 & 70 \\
8 & Question 8 & 80 \\
9 & Question 9 & 90 \\
$\mathbf{1 0}$ & Question 10 & $\mathbf{1 0 0}$ \\
11 & Question 11 & 110 \\
12 & Question 12 & 120 \\
13 & Question 13 & 130 \\
14 & Question 14 & 140 \\
$\mathbf{1 5}$ & Question 15 & $\mathbf{1 5 0}$ \\
16 & Question 16 & 160 \\
17 & Question 17 & 170 \\
18 & Question 18 & 180 \\
19 & Question 19 & 190 \\
$\mathbf{2 0}$ & Question 20 & $\mathbf{2 0 0}$ \\
21 & Question 21 & 210 \\
22 & Question 22 & 220 \\
23 & Question 23 & 230 \\
$\mathbf{2 6}$ & Question 24 & 240 \\
\hline & Question 25 & $\mathbf{2 5 0}$ \\
& Total & $\mathbf{2 5 0}$ \\
\hline & & \\
\hline & &
\end{tabular}

Questions are divided into 3 levels, each level consists of five questions.

Table 2. Question table of each level 


\begin{tabular}{ll}
\hline Level 1 & Question 1 - Question 6 \\
Level 2 & Question 7 - Question 14 \\
Level 3 & Question 15 - Question 25
\end{tabular}

A distinctive feature of LCM is that it repeats repeatedly in a certain period or after some generations. This is because of one trait with pseudo random generators in general. Determination of constant $L C M X_{n}=\left(\left(a\left(X_{n}-1\right)+b\right)\right)$ greatly determines whether or not the random number obtained in the sense of obtaining from some examples as below: Generating random bilanagan 8 times with a $=6, \mathrm{~b}=7, \mathrm{~m}=26$, and $\mathrm{X} 1=1$

$$
\begin{aligned}
& X 1=(6(1)+7) \text { vs. } 26=13 \\
& X 2=(6(13)+7) \text { vs. } 26=7 \\
& X 3=(6(7)+7) \text { vs. } 26=23 \\
& X 4=(6(23)+7) \text { vs. } 26=15 \\
& X 5=(6(15)+7) \text { vs. } 26=19 \\
& X 6=(6(19)+7) \text { vs. } 26=17 \\
& X 7=(6(17)+7) \text { vs. } 26=5 \\
& X 8=(6(15)+7) \text { vs. } 26=11
\end{aligned}
$$

The random number that a raises is $(13,7,23,15,19,17,5,11)$ does not see a repetition of the same number and on a period basis. The author can know that there is no periodic repetition every four randomizations from generating random numbers above. The result of randomization of the above values, will be used as an index of each question described when the user plays this game. For example, in the first round of questions posed by the system is index question number 1 . If the user successfully answers question number one correctly, then the question posed by the system in the second round is question number 2 and so on. In working LCM on the game guess, the face can be seen in the table of questions that appear that will be processed by lcm method randomly to determine the number of the question sequence. Generates a random number 12 times with $\mathrm{a}=6, \mathrm{~b}=7, \mathrm{~m}=$ 26 , and $\mathrm{X} 0=1$

$$
\begin{aligned}
& X 1=(6(1)+7) \text { vs. } 26=13 \\
& X 2=(6(13)+7) \text { vs. } 26=7 \\
& X 3=(6(7)+7) \text { vs. } 26=23 \\
& X 4=(6(23)+7) \text { vs. } 26=15 \\
& X 5=(6(15)+7) \text { vs. } 26=19
\end{aligned}
$$

And so on for the following calculation until it is completed. The calculation process in the LCM method is randomly assigned to determine the number of the question sequence to be raised randomly. In one safe point only as many as 5 questions. The user will select one of the answer options displayed for the user to choose the provided answer. In the example above, the question is limited to 25 questions to reach 250. The scoring process of this game is if you can answer the first randomized question get a score of 10, then can answer the second randomized question get a score of 20 and so on until the 25th question reaches the highest value. To get the bonus score, the user must be at the 1st level by answering 6 questions correctly. Automatically getting the first safe point bonus of 60 points, then reaching the 2 nd level must execute 10 questions with an automatic additional bonus score of 120 points. The next level must complete the question correctly and get the score to reach the highest score, which is 250 points.

\section{CONCLUSION}

From the results of the previous writing, conclusions can be drawn, where the findings may be helpful to the readers, so that thiselitian can be more helpful. The decisions are web-based face guessing games can be an exciting means of entertainment for its users. Linear Congruent Methods (LCM) algorithm can be used to randomize faces in the game application guess the face in presenting faces in each level. Linear Congruent Method algorithm can be applied to a web-based face thinking game application form. 


\section{REFERENCE}

[1] L. S. Muchlis and G. R. Septianus, "Game Edukasi Belajar Mengaji Menggunakan Metode Linear Congruent Method (LCM) Berbasis Android," J. Inform. Univ. Pamulang, vol. 5, no. 2, p. 120, 2020, doi: 10.32493/informatika.v5i2.5048.

[2] J. Naimah, D. S. Winarni, and Y. Widiyawati, "Pengembangan Game Edukasi Science Adventure Untuk Meningkatkan Keterampilanpemecahan Masalah Siswa," J. Pendidik. Sains Indones. (Indonesian J. Sci. Educ., vol. 7, no. 2, pp. 91-100, 2019, doi: 10.24815/jpsi.v7i2.14462.

[3] A. Arta and D. A. P. Putri, "Game Edukasi Pembelajaran Sejarah Berdirinya Indonesia untuk Sekolah Dasar," Emit. J. Tek. Elektro, vol. 20, no. 02, pp. 91-95, 2020, doi: 10.23917/emitor.v20i02.9085.

[4] E. Pambudi, I. Fitri, and S. Ningsih, "Perancangan Aplikasi Game IQ Test dengan Mengimplementasikan Linear Congruent Method ( LCM ) IQ Test Game Application Design By Implementing Linear Congruent Method," vol. 9, no. 2, pp. 193-198, 2021, doi: 10.26418/justin.v9i2.43329.

[5] D. Setiyadi, "Aplikasi Pembelajaran Mengetik Cepat Berbasis Game Edukasi dengan Linear Congruent Method (LCM)," Bina Insa. ICT J., vol. 3, no. 1, pp. 205-212, 2016, [Online]. Available: https://media.neliti.com/media/publications/234345-aplikasi-pembelajaranmengetik- cepat-ber-c9587a12.pdf.

[6] D. R. Purnamasari, "Implementasi Linear Congruent Method ( Lcm ) Pada Game Hangaroo Berbasis Android," J. Ris. Komput., vol. 3, no. Lcm, pp. 1-6, 2016.

[7] E. P. Syiamtoni, I. Fitri, and S. Ningsih, "PERANCANGAN APLIKASI GAME IQ TEST DENGAN MENGIMPLEMENTASIKAN LINEAR CONGRUENT METHOD (LCM), J. Inf. Technol. Comput. Sci., vol. 3, no. 2, pp. 328-335, 2020.

[8] A. P. Jumala, R. Parlika, and F. A. Akbar, "PERANCANGAN SISTEM UJIAN ONLINE DAN IMPLEMENTASI ALGORITMA LCM DALAM FITUR PENGACAKAN SOAL," J. Inform. dan Sist. Informasi(JIFoSI), vol. 1, no. 2, pp. 302-311, 2020.

[9] D. Irsa, R. Wiryasaputra, and S. Primaini, "Perancangan Aplikasi Game Edukasi Pembelajaran Anak Usia Dini Menggunakan Linear Congruent Method ( Lcm ) Berbasis Android," J. Inform. Glob., vol. 6, no. 1, pp. 7-14, 2015.

[10] S. Supriyadi, D. Hamdani, and Y. M. Furqon, "Rancang Bangun Alfabet Memory Game Menggunakan Linear Congruent Method ( Lcm )," vol. 45513, no. 36. 